\title{
Gambaran Kejadian Malaria Pada Ibu Hamil di Rumah Sakit Umum Daerah Kabupaten Boven
} Digoel Papua

\author{
Overview of Malaria Incidence in Pregnant Women at the Regional General Hospital in Boven \\ Digoel Regency in Papua \\ ${ }^{1}$ Halmina Ilyas, ${ }^{2}$ Serly \\ 1,2 Sekolah Tinggi Ilmu Kesehatan (STIK) Makassar, Indonesia
}

\author{
ARTICLE INFO \\ Article history : \\ Received 2021-June-13 \\ Received in revised form 2021-June-14 \\ Accepted 2021-June-19 \\ Keywords : \\ pregnant women incident \\ pregnant mother \\ Kata Kunci : \\ Kejadian Malaria \\ Ibu Hamil, Program KIA \\ Correspondence : \\ Halmina Ilyas \\ Email : halminailyas@gmail.com
}

\begin{abstract}
In malaria endemic areas, pregnant women are more susceptible to infection with malaria parasites than non-pregnant women. The World Health Organization (WHO) in 2014 estimated that 10,000 maternal deaths each year were associated with malaria infection during pregnancy. The purpose of the study was to describe the incidence of malaria in pregnant women at the Boven Digoel District General Hospital, Papua. Methods This research uses a descriptive type of research. Samples were taken as many as 92 pregnant women who were taken by accidental sampling. Data collection by using a questionnaire sheet. Data analysis was carried out univariate and bivariate. The results showed that from 78 pregnant women who were positive for malaria, most of them suffered from anemia as many as 51 people $(65.4 \%)$ and 27 people did not suffer from anemia (34.6\%). For the incidence of abortion from 78 pregnant women who were positive for malaria, most of them did not experience an abortion as many as 62 people (79.5\%) and 16 people had an abortion $(20.5 \%)$. For the habit of being out of the house at night, from 78 pregnant women who were positive for malaria, most of them were always outside at night as many as 41 people $(52.6 \%)$ and 37 people $(47,4 \%)$. The conclusion of this study, the description of the incidence of malaria in pregnant women mostly suffer from anemia, do not have abortions and are always outside the house at night. The advice that can be given is that malaria in pregnant women must be eradicated immediately so that the $\mathrm{MCH}$ program made by the government can be successful and the health of pregnant women can be maintained.
\end{abstract}

\begin{abstract}
ABSTRAK
Di daerah endemi malaria, wanita hamil lebih mudah terinfeksi parasit malaria dibandingkan wanita tidak hamil. World Health Organization (WHO) tahun 2014 memperkirakan bahwa 10.000 kematian ibu setiap tahun berhubungan dengan infeksi malaria selama kehamilan. Tujuan Penelitian untuk mengetahui gambaran kejadian malaria pada ibu hamil di Rumah Sakit Umum Daerah Kabupaten Boven Digoel Papua. Metode Penelitian ini menggunakan jenis penelitian deskriptif. Sampel yang diambil sebanyak 92 ibu hamil yang diambil secara accidental sampling. Pengumpulan data dengan cara menggunakan lembar kuesioner. Analisis data dilakukan secara univariat, dan bivariat. Hasil penelitian menunjukkan dari $78 \mathrm{ibu}$ hamil yang positif menderita malaria sebagian besar menderita anemia sebanyak 51 orang $(65,4 \%)$ dan tidak menderita anemia sebanyak 27 orang $(34,6 \%)$. Untuk kejadian abortus dari 78 ibu hamil yang positif menderita malaria sebagian besar tidak mengalami abortus sebanyak 62 orang $(79,5 \%)$ dan mengalami abortus sebanyak 16 orang $(20,5 \%)$. Untuk kebiasaan berada di luar rumah pada malam hari dari 78 ibu hamil yang positif menderita malaria sebagian besar selalu berada di luar rumah pada malam hari sebanyak 41 orang $(52,6 \%)$ dan tidak berada di luar rumah pada malam hari sebanyak 37 orang $(47,4 \%)$. Simpulan dari penelitian ini, gambaran kejadian malaria pada ibu hamil sebagian besar menderita anemia, tidak mengalami abortus dan selalu berada di luar rumah pada malam hari. Saran yang dapat diberikan adalah penyakit malaria pada ibu hamil harus segera diberantas agar Program KIA yang dibuat oleh pemerintah dapat berhasil dan kesehatan pada ibu hamil dapat terjaga.
\end{abstract}

\section{PENDAHULUAN}

Malaria merupakan penyakit akibat infeksi protozoa genus Plasmodium yang ditularkan melalui gigitan nyamuk Anopheles betina yang terinfeksi. Gejala umumnya muncul 10 hingga 15 hari setelah tergigit nyamuk Anopheles berupa demam ringan yang hilang timbul, sakit kepala, sakit otot dan mengigil bersaman dengan perasaan tidak enak (malaise). Penyakit ini dapat menyerang semua individu tanpa membedakan umur, jenis kelamin, dan tidak terkecuali wanita hamil. Wanita hamil termasuk golongan yang rentang untuk terkena malaria sehubungan dengan penurunan imunitas dimasa kehamilan.(1)

Malaria pada kehamilan dapat menyebabkan anemia merupakan kadar hemoglobin $(\mathrm{Hb})$ kurang dari 11 gram/dl. Anemia yang terjadi pada trimester pertama kehamilan Hal ini disebabkan karena pertumbuhan janin terjadi sangat pesat terjadi pada usia kehamilan sebelum 20 minggu. Anemia akibat malaria terjadi karena pecahnya eritrosit yang terinfeksi dan yang tidak

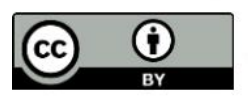


terinfeksi pecahnya eritrosit yang tidak terinfeksi terjadi akibat meningkatnya fragilitas osmotik sehingga mengakibatkan autohemolisis.(2)

Di daerah endemi malaria, wanita hamil lebih mudah terinfeksi parasit malaria dibandingkan wanita tidak hamil. Kemudahan infeksi itu terjadi karena kekebalan yang menurun selama kehamilan, akibatnya dapat terjadi peningkatan Prevalensi densitas parasit malaria berat.(3) World Health Organization (WHO) tahun 2014 memperkirakan bahwa 10.000 kematian ibu setiap tahun berhubungan dengan infeksi malaria selama kehamilan. Lebih dari sepertiga kematian ibu hamil terkait malaria, terjadi pada remaja primigravida, terutama berhubungan dengan anemia berat. Sebuah studi yang dilakukan di Rumah Sakit Rujukan Utama di Gambia mendapatkan kejadian kematian ibu meningkat 168 persen pada saat wabah malaria dan proporsi kematian akibat anemia meningkat tiga kali. Diperkirakan bahwa malaria berkontribusi pada 93 kematian ibu per 100.000 kelahiran hidup. Laporan dari berbagai Negara menunjukan insiden Malaria pada wanita hamil umumnya cukup tinggi, dari El Vador 55,75\% yaitu 63 kasus dari 113 wanita hamil; dari berbagai tempat bervariasi antara 2-76\%. (4)

Di Indonesia, data Profil Kesehatan Indonesia tahun 2015 menyebutkan bahwa daerah endemis sedang malaria terjadi penurunani 18,6\% tahun 2011 menjadi $17 \%$ pada tahun 2015, serta daerah endemis rendah juga mengalami menurun yang tajam dari 42,8\% pada tahun 2011 menjadi 28,8\% pada tahun 2015. Pada survei ini tiga provinsi dengan insiden tertinggi sama dengan hasil laporan rutin yaitu Papua $(6,1 \%)$, Papua Barat (4,5\%), dan Nusa Tenggara Timur $(2,6 \%)$. Sementara insiden malaria berdasarkan diagnosis/gejala sebesar 1,9\% atau 19 per 1.000 penduduk. (Kementerian Kesehatan RI, 2016). Upaya pemerintah dalam program pengendalian malaria yaitu Diagnosa Malaria harus terkonfirmasi mikroskop atau Rapid Diagnostic Test; Pengobatan menggunakan Artemisinin Combination Therapy; Pencegahan penularan malaria melalui: distribusi kelambu (Long Lasting Insecticidal Net), penyemprotan rumah, repellent, dan lain-lain, kerjasama lintas sektor dalam Forum Gebrak Malaria, dan Memperkuat Desa Siaga dengan pembentukan Pos Malaria Desa.(5)

Kabupaten Boven Digoel merupakan salah satu wilayah endemis malaria di Provinsi Papua. Berdasarkan profil kesehatan Papua tahun 2016, ditemukan kejadian malaria ibu hamil 2071 (33,1\%) dan tahun 2017 jumlah kasus malaria pada ibu hamil mengalami penurunan yaitu sebanyak 987 kasus. Angka ini masih jauh dari target Millennium Development Goals (MDGs).(6)

\section{METODE}

Jenis penelitian yang digunakan adalah jenis penelitian deskriptif, yaitu penelitian yang digunakan untuk membuat gambaran kejadian Malaria Pada ibu hamil di Rumah Sakit Umum Daerah Kabupaten Boven Digoel Papua. Sampel dalam penelitian ini ibu hamil yang berkunjung di Rumah Sakit Umum Daerah Kabupaten Boven Boven Digoel Papua dengan jumlah 92 sampel.

\section{HASIL DAN PEMBAHASAN}

\section{HASIL}

\section{Karakteristik Responden}

Tabel.1 Karakteristik Responden Berdasarkan Kelompok Umur Ibu, Tingkat Pendidikan, Pekerjaan Di Rumah Sakit Umum Daerah Kabupaten Boven Boven Digoel Papua Tahun 2019

\begin{tabular}{|c|c|c|}
\hline Umur & $\mathrm{n}=92$ & $\%=100$ \\
\hline$<20$ Tahun & 2 & 2,2 \\
\hline 20 - 35 Tahun & 81 & 88,0 \\
\hline$>35$ Tahun & 9 & 9,8 \\
\hline Pendidikan & $\mathrm{n}=92$ & $\%=100$ \\
\hline SD & 28 & 30,4 \\
\hline SMP & 25 & 27,2 \\
\hline SMA & 29 & 31,5 \\
\hline S1 & 10 & 10,9 \\
\hline \multicolumn{3}{|l|}{ Pekerjaan } \\
\hline PNS & 5 & 5,4 \\
\hline Wiraswasta & 48 & 52,2 \\
\hline Pegawai Swasta & 6 & 6,5 \\
\hline Petani & 3 & 3,3 \\
\hline IRT & 30 & 32,6 \\
\hline
\end{tabular}

Sumber : Data Primer

Tabel.1 menunjukkan bahwa distribusi responden menurut kelompok umur, persentase tertinggi berada pada kelompok umur 20-35 tahun yaitu sebanyak 81 orang (88.0\%) sedangkan persentase terendah berada pada kelompok umur $<20$ tahun yaitu sebanyak 2 orang (2,2\%). Distribusi Pendidikan responden dengan persentase tertinggi adalah SMA yaitu sebanyak 29 orang (31,5\%) Dan persentase terendah adalah berpendidikan S1 yaitu 10 orang (10,9\%). Untuk pekerjaan persentase tertinggi 
yang bekerja sebagai Wiraswasta yaitu sebanyak 48 orang $(52,2 \%)$. Sedangkan persentase terendah adalah bekerja sebagai petani yaitu 3 orang $(3,3 \%)$.

\section{Analisis Univariat}

\section{Anemia pada Ibu Hamil}

Tabel.2 Distribusi Responden Berdasarkan anemia pada ibu hamil Di Rumah Sakit Umum Daerah Kabupaten Boven Boven Digoel Papua Tahun 2019

\begin{tabular}{lcc}
\hline Anemia & $\mathrm{n}=92$ & $\%=100$ \\
\hline Anemia & 51 & 55,4 \\
Tidak Anemia & 41 & 44,6
\end{tabular}

Sumber : Data Primer

Tabel 2 menunjukkan bahwa distribusi responden menurut kejadian anemia pada ibu hamil dengan persentase tertinggi pada responden yang mengalami anemia yaitu sebanyak 51 orang $(55,4 \%)$ sedangkan persentase terendah berada pada responden yang tidak mengalami anemia yaitu sebanyak 41 orang $(44,6 \%)$.

\section{Abortus}

Tabel.3 Distribusi Responden Berdasarkan Abortus pada ibu hamil Di Rumah Sakit Umum Daerah Kabupaten Boven Boven Digoel Papua Tahun 2019

\begin{tabular}{lcc}
\hline Abortus & $\mathrm{n}=92$ & $\%=100$ \\
\hline Abortus & 16 & 17,4 \\
Tidakn Abortus & 76 & 82,6 \\
\hline
\end{tabular}

Sumber : Data Primer

Tabel.3 menunjukkan bahwa distribusi responden menurut kejadian abortus pada ibu hamil dengan persentase tertinggi pada responden yang tidak mengalami abortus pada saat hamil yaitu sebanyak 76 orang $(82,6 \%)$ sedangkan persentase terendah berada pada responden yang mengalami abortus pada saat hamil yaitu sebanyak 16 orang $(17,4 \%)$.

\section{Kebiasaan Berada Diluar Rumah pada Malam Hari}

Tabel.4 Distribusi Responden Berdasarkan Kebiasaan Berada di Luar Rumah pada Malam Hari Di Rumah Sakit Umum Daerah Kabupaten Boven Boven Digoel Papua Tahun 2019

\begin{tabular}{lcc}
\hline Kebiasaan Berada Diluar Rumah & $\mathrm{n}=92$ & $\%=100$ \\
pada Malam Hari & & 51,1 \\
\hline Ya & 47 & 48,9 \\
Tidak & 45 & \\
\hline
\end{tabular}

\section{Sumber : Data Primer}

Tabel 4 menunjukkan bahwa distribusi responden menurut kebiasaan berada di luar rumah pada malam hari dengan persentase tertinggi pada responden yang selalu berada di luar rumah pada malam hari yaitu sebanyak 47 orang (51,1\%) sedangkan persentase terendah berada pada responden yang berada di luar rumah pada malam hari yaitu sebanyak 45 orang $(48,9 \%)$.

\section{Kejadian Malaria pada Ibu Hamil}

Tabel.5 Distribusi Responden Berdasarkan Kejadian Malaria Pada ibu hamil Di Rumah Sakit Umum Daerah Kabupaten Boven Boven Digoel Papua Tahun 2019

\begin{tabular}{lcc}
\hline Kejadian Malaria pada Ibu Hamil & $\mathrm{n}=92$ & $\%=100$ \\
\hline Positif & 78 & 84,8 \\
Negatif & 14 & 15,2 \\
\hline
\end{tabular}

Sumber : Data Primer 
Tabel.5 menunjukkan bahwa distribusi responden menurut kejadian Malaria Pada ibu hamil dengan persentase tertinggi pada responden positif menderita malaria selama kehamilan yaitu sebanyak 78 orang $(84,8 \%)$ sedangkan persentase terendah berada pada responden yang negatif menderita malaria selama kehamilan yaitu sebanyak 14 orang $(15,2 \%)$.

\section{Gambar Anemia dengan Kejadian Malaria pada Ibu Hamil}

Tabel.6 Gambaran Anemia Dengan Kejadian Malaria Pada Ibu Hamil Di Rumah Sakit Umum Daerah

Kabupaten Boven Boven Digoel Papua Tahun 2019

\begin{tabular}{|c|c|c|c|c|c|c|}
\hline \multirow{3}{*}{ Anemia } & \multicolumn{4}{|c|}{ Kejadian Malaria pada Ibu Hamil } & \multirow{2}{*}{\multicolumn{2}{|c|}{ Total }} \\
\hline & \multicolumn{2}{|c|}{ Positif } & \multicolumn{2}{|c|}{ Negatif } & & \\
\hline & $\mathrm{n}$ & $\%$ & $\mathrm{n}$ & $\%$ & $\mathrm{n}$ & $\%$ \\
\hline Anemia & 51 & 65,4 & 0 & 0 & 51 & 55,4 \\
\hline Tidak Anemia & 27 & 34,6 & 14 & 100 & 41 & 44,6 \\
\hline Total & 78 & 100 & 14 & 100 & 92 & 100,0 \\
\hline
\end{tabular}

Sumber : Data Primer

Berdasarkan tabel.6 tentang gambaran anemia dengan kejadian malaria pada ibu hamil di rumah Sakit Umum Daerah Kabupaten Boven Boven Digoel Papua menunjukkan dari 78 ibu hamil yang positif menderita malaria sebagian besar menderita anemia sebanyak 51 orang $(65,4 \%)$ dan tidak menderita anemia sebanyak 27 orang (34,6\%). Sedangkan dari 14 ibu hamil yang negatif tidak menderita malaria sebagian besar tidak menderita anemia sebanyak 14 orang (100\%).

\section{Gambar Abortus dengan Kejadian Malaria pada Ibu Hamil}

Tabel.7 Gambaran Abortus dengan Kejadian Malaria Pada Ibu Hamil Di Rumah Sakit Umum Daerah Kabupaten Boven Boven Digoel Papua Tahun 2019

\begin{tabular}{|c|c|c|c|c|c|c|}
\hline \multirow{3}{*}{ Abortus } & \multicolumn{4}{|c|}{ Kejadian Malaria pada Ibu Hamil } & \multirow{2}{*}{\multicolumn{2}{|c|}{ Total }} \\
\hline & \multicolumn{2}{|c|}{ Positif } & \multicolumn{2}{|c|}{ Negatif } & & \\
\hline & $\mathrm{n}$ & $\%$ & $\mathrm{n}$ & $\%$ & $\mathrm{n}$ & $\%$ \\
\hline Abortus & 16 & 20,5 & 0 & 0 & 16 & 17,4 \\
\hline Tidak Abortus & 62 & 79,5 & 14 & 100 & 76 & 82,6 \\
\hline Total & 78 & 100 & 14 & 100 & 92 & 100,0 \\
\hline
\end{tabular}

Sumber : Data Primer

Berdasarkan tabel.7 tentang gambaran abortus dengan kejadian malaria pada ibu hamil di rumah Sakit Umum Daerah Kabupaten Boven Boven Digoel Papua menunjukkan dari 78 ibu hamil yang positif menderita malaria sebagian besar tidak mengalami abortus sebanyak 62 orang $(79,5 \%)$ dan mengalami abortus sebanyak 16 orang (20,5\%). Sedangkan dari 14 ibu hamil yang negatif tidak menderita malaria sebagian besar tidak mengalami abortus sebanyak 14 orang (100\%)

\section{Gambar Berat Badan Lahir Rendah dengan Kejadian Malaria pada Ibu Hamil}

Tabel.8 Gambaran Berat Badan Lahir Rendah dengan Kejadian Malaria Pada Ibu Hamil Di Rumah Sakit Umum Daerah Kabupaten Boven Boven Digoel Papua Tahun 2019

\begin{tabular}{|c|c|c|c|c|c|c|}
\hline \multirow{3}{*}{ Berat Badan Lahir Rendah } & \multicolumn{4}{|c|}{ Kejadian Malaria pada Ibu Hamil } & \multirow{2}{*}{\multicolumn{2}{|c|}{ Total }} \\
\hline & \multicolumn{2}{|c|}{ Positif } & \multicolumn{2}{|c|}{ Negatif } & & \\
\hline & $\mathrm{n}$ & $\%$ & $\mathrm{n}$ & $\%$ & $\mathrm{n}$ & $\%$ \\
\hline $\mathrm{Ya}$ & 12 & 15,4 & 0 & 0 & 12 & 13,0 \\
\hline Tidak & 66 & 84,6 & 14 & 100 & 80 & 87,0 \\
\hline Total & 78 & 100 & 14 & 100 & 92 & 100,0 \\
\hline
\end{tabular}

Sumber : Data Primer

Berdasarkan tabel 9 tentang gambaran berat badan lahir rendah dengan kejadian malaria pada ibu hamil di rumah Sakit Umum Daerah Kabupaten Boven Boven Digoel Papua menunjukkan dari 78 ibu hamil yang positif menderita malaria sebagian besar tidak mengalami berat badan lahir rendah sebanyak 66 orang $(84,6 \%)$ dan tidak mengalami berat badan lahir rendah sebanyak 12 orang $(15,4 \%)$. Sedangkan dari $14 \mathrm{ibu}$ hamil yang negatif tidak menderita malaria sebagian besar tidak mengalami berat badan lahir rendah sebanyak 14 orang $(100 \%)$. 


\section{PEMBAHASAN}

\section{Karakteristik Responden}

\section{Umur}

Berdasarkan dari hasil penelitian di dapatkan bahwa sebagian besar responden dari jumlah 92 orang adalah kelompok umur 20-35 tahun yaitu sebanyak 81 orang $(88.0 \%)$ dan yang paling rendah yaitu umur < 20 tahun yaitu sebanyak 2 orang (2.2\%). Asumsi peneliti kehamilan pada umur < 20 tahun atau > 35 tahun merupakan kehamilan yang berisiko tinggi dibandingkan dengan kehamilan pada wanita yang berumur 20-35 tahun, hal tersebut disebabkan kehailan <20 tahun dinilai terlalu mudda yang secara fisik perkembangan organ reproduksi maupun fungsi fisiologi bekum optimal dan secara mental belum siap menghadapi pereubahan yang terjadi saat kehamilan, menjalankan peran sebagai ibu juga dalam menghadapi masalah-masalah rumah tangga. Kondisi mental dan fisik yang belum matang akan meningkatkan risiko terjadinya persalinan yang sulit dengan komplikasi medis diataranya keguguran, pre eklamsi (tekanan darah tinggi), eklamsia (keracunan kehamilan) persalinan lama, bayi lahir prematur, perdarahan yang berujung pada kematian ibu dan bayi. Kehamilan > 35 tahun dinilai terlalu tua karena diusia tersebut faktor degeneratif menyebabkan fungsi rahim mulai menurun begitu juga kondisi ibu mulai yang ikut menurun yang tentu saja memberi resiko terjadinya kesulitan persalinandengan komplikasi medis

\section{Pendidikan}

Berdasarkan penelitian ini sebagian besar responden berada dikelompok berpendidikn rendah dan menengah. Dari hasil penelitian menunjukkan bahwa pola distribusi pada penyakit malaria ibu hamil tidak dipengaruhi oleh tingkat pendidikan seseorang. Diketahui bahwa penderita malaria yang berpendidikan SD sebanyak 30,4\%, yang berpendidikan SMP sebanyak 27,2\% dan yang berpendidikan SMA 31,5\% sedangkan yang pendidikannya tinggi hanya 10,9\%. Kejadian malaria pada ibu hamil disebabkan karena terganggunya keseimbangan antara pejamu (manusia dan nyamuk Anopheles sp), agent (plasmodium) dan lingkungan. Pada manusia salah satu faktor yang mempengaruhi adalah perilaku yang tersusun atas pengetahuan, sikap dan tindakan. Walaupun malaria angka kematiaannya rendah tapi morbilitasnya (angka kematian) tinggi yang dapat menyebabkan daya tahan tubuh rendah, daya kerja menurun, menghambat lancarnya keparawisataan karena adanya malaria disuatu kawasan objek wisata.(7)

\section{Pekerjaan}

Berdasarkan dari hasil penelitian menunjukkan bahwa sebagian besar responden adalah wiraswasta yaitu sebanyak 48 orang $(52,2 \%)$ dan yang paling rendah yaitu petani sebanyak 3 orang $(3,3 \%)$. Berdasarkan hasil penelitian menunjukkan bahwa penderita penyakit malaria ibu hamil lebih banyak diderita oleh pendudukyang bekerja sebagai wiraswasta yaitu sebanyak 48 orang $(52,2 \%)$ sebagian besar adalah pedagang dipasar, maka peluang orang tertular malaria akan semakin besar. Perpindahan penduduk dari dan kedaerah endemis malaria hingga kini masih menimbulkan masalah hal ini terjadi karen pekerja yang datang dari daerah yang lain belum mempunyai kekebalan sehingga rentan terinfeksi.

\section{Variabel yang Diteliti}

\section{Anaemia pada Ibu Hamil}

Berdasarkan dari hasil penelitian menujukkan bahwa distribusi responden menurut kejadian anemia pada ibu hamil dengan presentase tertinggi yang mengalami anemia yaitu sebanyak 51 orang $(55,4 \%)$ sedangkan persentase terendah berada pada responden yang tidak mengalami anemia yaitu sebanyak 41 orang (44,6\%). Proses kehamilan yang menjadi faktor individu akan memperberat kasus malaria yang dialami oleh ibu hamil dan seorang ibu hamil yang menderita malaria akan berpengaruh pada proses kehamilan dan kelainan pada bayi yang bru dilahirkan. Infeksi malaria pada ibu hamil dapat menyebabkan anemia pada ibu dan janinnya meningkat 2 kali dibandingkan dengan ibu hamil tanpa malaria. Hal ini dapat meningkatkan angka kematian ibu dan bayi. Infeksi pada wanita hamil yang disebabkan oleh parasit malaria ini sangat mudah terjadi, karena disebakan oleh adanya perubahan sistem imunitas ibu selama kehamilan baik imunitas seluler maupun imunitas humoral, serta diduga juga akibat peningkatan hormon kortisol pada wanita selama kehamilan.
Abortus
Berdasarkan hasil penelitan menunjukkan bahwa distribusi responden meurut kejadian abortus pada ibu hamil dengan presentase tertinggi pada responden yang tidak mengalami abortus pada saat hamil yaitu sebanyak 76 orang (82,6\%) sedangkan persentase terendah berada pada responden yang mengalami abortus pada saat hamil yaitu sebanyak 16 orang $(17,4 \%)$. Abortus pada usia kehamilan trimester 1 lebih sering terjadi karena demam tinggi sedangkan abortus pada usia trimester II disebabkan oleh anemia berat. Ibu hamil yang menderita malaria dapat berakibat buruk pada janin yang

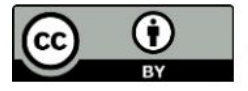


kandungnya. Pengaruh pada janin yang paling sering terjadi adalah Berat Badan Lahir Rendah (BBLR). Bayi yang lahir dengan berat badan rendah dapat disebabkan oleh kelahiran prematur dan gangguan pertumbuhan janin. Kondisi ini dapat terjadi akibat malaria dimasa kehamilan karena adanya gangguan supai nutrisi dan oksigen dari ibu kejanin yang dikandungnya. Gangguan sirkulasi uteroplasenta terjadi akibat adanya sekuestrasi eritrosit terinfeksi yang terus mengkomsumsi glukosa dan oksigen eritrosit, terjadinya penebalan membran sitotroplasma dan kondisi anemia pada ibu. Selain itu proses inflamasi yang diperantarai oleh sitokin Th1 akibat infeksi parasit malaria ini juga mempengaruhi secara langsung proses tumbuh kembang janin. Apabila infeksi yang terjadi cukup berat, malaaria dimasa kehamilan dapat mengakibatkan abortus atau stillbirth.

\section{Kebiasaan Berada Di Luar Rumah pada Malam Hari}

Berdasarkan hasil penelitian menunjukkan hasil distribusi responden menurut kebiasaan berada di luar rumah pada malam hari dengan persentase tertinggi pada responden yang selalu berada di luar rumah pada malam hari yaitu sebanyak 47 orang $(51,1 \%)$ sedangkan persentase terendah berada pada responden yang berada di luar rumah pada malam hari yaitu sebanyak 45 orang (48,9\%). Perilaku ibu hamil dalam beraktifitas diluar rumah malam hari didukung karena adanya kegiatan wirausaha yaitu berdagang yang digeluti oleh ibu hamil hingga malam hari. Selain itu, ada juga yang sekedar pergi kewarung membeli kebutuhan dan pergi menonton televisi dirumah tetangga. Berbagai kebiasaan ini dapat mempermudah terjadinya kontak ddengan nyamuk penular malaria. Hal ini sesuai dengan yang telah dijelaskan dalam Kemenkes (2014) bahwa kebiasaan berada diluar rumah sampai larut malam dapat mempermudah kontak dengan nyamuk penular malaria, apalagi nyamuk yang memang sifatnya lebih suka beritirahat dan menggigit diluar rumah.(5) Nyamuk-nyamuk tersebut mempunyai sifat lebih senang beristirahat dan menggigit diluar rumah.(8)

\section{Kejadian Malaria pada Ibu Hamil}

Berdasarkan hasil penelitian menunjukkan bahwa distribusi responden menurut kejadian Malaria Pada ibu hamil dengan persentase tertinggi pada responden positif menderita malaria selama kehamilan yaitu sebanyak 78 orang $(84,8 \%)$ sedangkan persentase terendah berada pada responden yang negatif menderita malaria selama kehamilan yaitu sebanyak 14 orang $(15,2 \%)$. Malaria adalah penyakit parasit yang resikonya lebih tinggi pada ibu hamil dibandingkan dengan mereka yang tidak hamil, terutama selama kehamilan pertama yang dapat menyebabkan infeksi plasenta, abortus, meninggal dalam kandungan, anemia dan berat badan lahir rendah. Pengaruh utama malaria selama kehamilan adalah terutama pada ibu dan janinnya. Infeksi malaria P. Falciparum pada ibu hamil dalam trimester pertama. Kehamilan harus dirawat dengan quinine (Kina). Setelah trimester II kehamilan maka ACT (amodiaquine da artesunat) akan digunakan untuk perawatan malaria.

\section{Gambaran Kejadian Malaria pada Ibu Hamil Di Rumah Sakit Umum Daerah Kabupaten Boven Digoel Papua Tahun 2019}

\section{Gambaran Anemia dengan Kejadian Malaria pada Ibu Hamil}

Anemia pada malaria terjadi karena lisis sel darah merah yang mengandung parasit. Hubungan antara anemia dan splenomegali dilaporkan oleh Brabin yang melakukan penelitian pada wanita hamil di Papua Neu Geuinea, dan menyatakan bahwa makin besar ukuran limpa makin rendah nilai Hb-nya.(9) Berdasarkan hasil penelitian Rumah Sakit Umum Daerah Kabupaten Boven Boven Digoel Papua menunjukkan dari 78 ibu hamil yang positif menderita malaria sebagian besar menderita anemia sebanyak 51 orang $(65,4 \%)$ dan tidak menderita anemia sebanyak 27 orang (34,6\%). Sedangkan dari 14 ibu hamil yang negatif tidak menderita malaria sebagian besar tidak menderita anemia sebanyak 14 orang (100\%). Hasil penelitian sejalan dengan penelitian Ayoya MA. Et.al. (2016) didapatkan bahwa 47\% dari 190 ibu hamil yang diskrining malaria mengalami penurunan kadar $\mathrm{Hb}(\mathrm{Hb}<11 \mathrm{~g} / \mathrm{dL})$ dan $13 \%$ mengalami penurunan kadar Fe serum (Fe serum $<12$ mikromol/L). Ibu hamil yang terinfeksi malaria vivax juga disertai dengan penurunan kadar Fe serum. Penurunan kadar Fe serum menunjukan bahwa terjadi penurunan cadangan besi yang ada di dalam tubuh. Parasit malaria membutuhkan zat besi untuk kelangsungan hidupnya dari tubuh hospes.(10) Zat besi dibutuhkan untuk aktivitas enzimatik, pernapasan dan reaksi redoks. Lebih kurang 25-75\% hemoglobin dicerna di dalam vakuola makanan selama fase pertumbuhan parasit. Zat besi diperoleh dari pemecahan hemoglobin, plasma transferin yang mengikat zat besi dan feritin intra sel. Zat besi dapat memengaruhi respons imun sehingga akan berpengaruh terhadap infeksi seseorang.(11)

Hal ini sejalan pula dengan survei malaria pada kehamilan tahun 2017 di Kisumu, Western Kenya. Dari 685 ibu hamil yang berkunjung ke pusat pelayanan kesehatan, 18\% menderita malaria. Dari survei tersebut, didapatkan 69,1\% dari yang menderita malaria tersebut mengalami anemia $(\mathrm{Hb}<11 \mathrm{~g} / \mathrm{dL})$ dan 11,8\% mengalami moderate anemia. Mekanisme anemia yang terjadi disebabkan oleh plasmodium menginvestasi eritrosit sehingga berdampak pada penekanan produksi eritropoetin dan gangguan eritropoesis akibat produksi sitokin pada proses inflamasi. Eritrosit yang diinvestasi oleh plasmodium

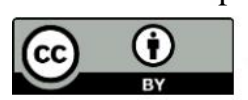


mengalami kelainan sehingga permukaan sel menjadi tidak teratur. Kerusakan eritrosit tersebut akan menyebabkan anemia, anoksia jaringan dan hemolisis intravaskuler. Kemungkinan akan sulit untuk menghubungkan anemia dengan sebuah penyebab tunggal karena penyebab anemia malaria di daerah endemic biasanya kompleks dan defisiensi hematinin, sifat genetic, dan infeksi berulang kesemuanya itu berkontribusi terhadap anemia. Namun demikian, sebuah randomized placebo-controlled trial profilaksis malaria dan suplementasi besi pada bayi, pada sebuah daerah endemic, telah memperihatkan bahwa infeksi malaria merupakan faktor etiologi utama yang mendasari terjadinya anemia.(12) Di Afrika diperkirakan $25 \%$ anemia berat disebabkan oleh malaria kehamilan $(\mathrm{Hb}<11 \mathrm{~g} / \mathrm{dL})$. Wanita hamil dengan anemia berat mempunyai risiko lebih ting gi terhadap morbiditas seperti gagal jantung kongestif, kematian janin dan bahkan kematian akibat perdarahan saat melahirkan.(13)

Asumsi peneliti zat besi dapat mempengaruhi respons imun sehingga akan berpengaruh terhadap infeksi seseorang. Prosesatau respons imun spesifik membutuhkan zat besi dalam mengeleminasi mikroorganisme yang masuk ke dalam tubuh. Di lain pihak mikroorganisme juga membutuhkan zat besi ketika masuk ke dalam tubuh pejamu untuk proses multiplikasi (memperbanyak diri). Oleh karena itu, kekurangan zat besi dapat berhubungan dengan perubahan sistem imun dan kejadian infeksi, termasuk infeksi malaria. Ibu hamil yang terinfeksi malaria biasanya menderita anemia sehingga akan menyebabkan gangguan sirkulasi nutrisi pada janin dan berakibat pertumbuhan dan perkembangan janin dalam kandungan terhambat, berat badan lahir rendah dan kelahiran prematur. Kematian janin intra uterin juga dapat terjadi akibat hiperpireksi, anemia berat, penimbunan parasit di dalam plasenta yang menyebabkan gangguan sirkulasi ataupun akibat infeksi transplasental. Penimbunan parasit dalam plasenta terjadi pada ibu hamil yang terinfeksi malaria falsiparum.

\section{Gambaran Abortus dengan Kejadian Malaria pada Ibu Hamil}

Malaria dalam kehamilan adalah masalah bagi janin. Tingginya komplikasi-komplikasi kehamilan dapat menimbulkan efek buruk terhadap janin. Baik malaria $P$. vivax dan $P$. falciparum dapat menimbulkan masalah bagi janin, akan tetapi jenis infeksi P. falciparum lebih serius, akibatnya dapat terjadi saah satunya abortus spontan.(14) Abortus atau keguguran adalah terhentinya kehamilan sebelum janin dapat bertahan hidup, yaitu sebelum kehamilan berusia 22 minggu atau berat janin belum mencapai 500 gram. Abortus biasanya ditandai dengan terjadinya perdarahan pada wanita yang sedang hamil, dengan adanya peralatan USG. Berdasarkan hasil penelitian Rumah Sakit Umum Daerah Kabupaten Boven Boven Digoel Papua menunjukkan dari $78 \mathrm{ibu}$ hamil yang positif menderita malaria sebagian besar tidak mengalami abortus sebanyak 62 orang $(79,5 \%)$ dan mengalami abortus sebanyak 16 orang (20,5\%). Sedangkan dari 14 ibu hamil yang negatif tidak menderita malaria sebagian besar tidak mengalami abortus sebanyak 14 orang (100\%). Parasit malaria, baik plasmodium vivax maupun falciparum, memberikan kontribusi yang signifikan pada kematian janin dan bayi. Hasil ini menunjukkan bahwa efek berbahaya malaria pada trimester pertama kehamilan lebih besar daripada efek pengobatan. Kami menekankan pentingnya deteksi dini malaria serta pengobatan yang efektif untuk semua perempuan hamil dengan segara.

Hal ini sejalan dengan hasil penelitian Wiguna (2013) menunjukan bahwa 38,7 \% ibu hamil menderita malaria dan sebagian besar disebabkan oleh Plasmodium falciparum: 48,3\%. Plasmodium falciparum pada ibu hamil menyebabkan abortus 53,8 \%, Prematur 42,9\% dan perdarahan $60 \%$. Kejadian malaria pada ibu hamil pada trimester I menyebabkan 53,8 \% abortus, dan kejadian malaria pada trimester 3 menyebabkan 57,1\% prematur dan $40 \%$ perdarahan. Guna mengurangi komplikasi persalinan yang terjadi di Kecamatan Tanjung upaya yang utama adalah menurunkan kejadian penyakit malaria melalui pemberantasan vector baik secara biologi, kimia maupun pengendalian lingkungan dengan membuat source reduction pacta muara-muara sungai yang berbatasan dengan pantai, melakukan revitalisasi fungsi pustu dan polindes sebagai Pos Pengobatan Malaria Desa sehingga penanganan penderita malaria dapat dilakukan secara dini.(15) Para peneliti di Shoklo Malaria Research Unit menemukan bahwa satu episode malaria pada trimester pertama kehamilan terkait dengan peningkatan risiko keguguran sebesar tiga kali lipat. Risiko ini bukan terkait dengan pengobatan malaria, sebab peneliti menemukan bahwa perempuan yang diobati dengan obat anti malaria tidak mengalami efek samping yang serius atau meningkatkan kemungkinannya mengalami abortus / keguguran.(16)

Menurut peneliti bahaya malaria dapat menyerang siapa saja termasuk ibu hamil meskipun tingkat bahaya pada ibu hamil akan semakin meningkat dikarenakan pada ibu hamil seringkali mengalami perubahan secara fisiologi, perubahan hormon bahkan perubahan-perubahan pada jumlah cairan tubuh. Faktor-faktor tersebut yang dapat menambah resiko pada ibu hamil yang sedang di derita bahkan dapat menyerang anda dan janin. Kondisi yang membuat semakin berat ketika pada trimester pertama dan kedua dikarenakan bagian yang disenangi parasit malaria yaitu plasenta dimana menjadi salah satu sumber pertumbuhan janin yaitu makanan janin. Bahkan bagian kosong akan dipenuhi oleh parasit-parasit malaria sehingga parasit ini akan mengganggu saluran makanan janin sehingga saluran makan janin menjadi mengecil dan juga rusak sebagian. Akibatnya jatah makanan menuju janin akan terbagi dan terganggu berimbas pada perkembangan janin menjadi terhambat sehingga menyebabkan keguguran. Risiko keguguran pada ibu hamil dengan gejala malaria cenderung sampai empat kali lebih besar.

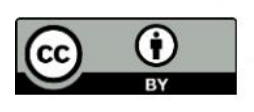


Risiko ini sama di antara perempuan dengan malaria Plasmodium vivax dan Plasmodium falcifarum.Secara teoritis penjelasan mengenai kaitan infeksi dan abnormalitas pertumbuhan janin adalah akibat kerusakan plasenta. Infeksi malaria menyebabkan penipisan membran dasar trofoblas. Sinusoid plasenta tertutup oleh pengumpalan eritrosit yang mengandung parasit, ini bersamaan dengan penumpukan makrofag intervillus dan deposit fibrin perivillus yang diduga sebagai penyebab obstruksi mikrosirkulasi dan penurunan aliran nutrisi terhadap janin. Sedangkan penelitian yang dilakukan oleh Dwiprahasto (2000) di kabupaten Jepara. Hasil di lapangan menunjukkan 2.527 dari 3.099 yang hamil telah melahirkan bayinya pada tahap akhir dari studi ini. Prevalensi parasit malaria yang ditemukan hanya 1,9\%. pada penelitian ini sebesar 2\%. Dari studi ini dapat disimpulkan bahwa di daerah endemik malaria dengan tingkat transmisi yang rendah, pada bayi dan anemia pada ibu jauh lebih besar dan bermakna secara statistik pada ibu yang menderita malaria selama kehamilan dibandingkan dengan ibu hamil yang tidak menderita malaria.(14)

Asumsi peneliti wanita hamil lebih mudah terinfeksi malaria dibanding dengan populasi umumnya. Selain mudah terinfeksi, wanita hamil juga mudah terinfeksi berulang hingga komplikasi berat, kehamilan memperberat penyakit malaria yang diderita, sebaliknya malaria akan berpengaruh pada kehamilan dan menyebabkan penyulit, baik terhadap ibu maupun janin yang dikandungnya sehingga meningkatkan kejadian morbiditas dan mortalilas ibu maupun janin. Interferensi parasit malaria dalam darah ibu hamil memberi dampak langsung baik pada ibu, plasenta, maupun bayi yang dikandungnya yang sering ditemukan pada ibu yang menderita malaria selama kehamilan menjadi lebih tinggi. diantaranya masalah psikis seperti gangguan bicara, gangguan perkembangan dan pertumbuhan, gangguan belajar dan masalah fisik seperti penyakit paru kronis dan kelainan bawaan.

\section{Gambaran Kebiasaan Berada Di Luar Rumah pada Malam Hari dengan Kejadian Malaria pada Ibu Hamil}

Kebiasaan keluar rumah malam hari pada jam nyamuk Anopheles spp. Aktif menggigit sangat berisiko untuk tertular malaria, dikarenakan nyamuk ini bersifat eksofagik dimana aktif mencari darah di luar rumah pada malam hari. Kebiasaan ini akan semakin berisiko jika orang terbiasa keluar rumah tanpa memakai pakaian pelindung seperti baju berlengan panjang dan celana panjang. Masyarakat di Kabupaten Boven Digoel Papua termasuk ibu hamil memiliki kebiasaan keluar rumah pada malam hari karena mereka pada umumnya bekerja dari pagi hingga sore hari yang sebagian besar pedagang, sehingga waktu malam hari akan dimanfaatkan untuk bersenda gurau dan bertemu dengan sanak keluarga disekitar rumah ataupun berkumpul dengan tetangga di warung kopi dan rumah tetangga. Masyarakat di berbagai daerah di Indonesia sering berkumpul dan bercengkerama dengan sanak keluarga pada malam hari, hal ini disebabkan masyarakat yang masih mengadakan berbagai acara seperti pernikahan, kelahiran bayi, adanya warga masyarakat meninggal dunia yang dilakukan pada malam hari sehingga kontak antara nyamuk Anopheles sp dengan manusia menjadi sangat sering, sehingga membuat resiko terkena gigitan nyamuk menjadi sangat besar.

Berdasarkan hasil penelitian Rumah Sakit Umum Daerah Kabupaten Boven Boven Digoel Papua menunjukkan dari 78 ibu hamil yang positif menderita malaria sebagian besar selalu berada di luar rumah pada malam hari sebanyak 41 orang (52,6\%) dan tidak berada di luar rumah pada malam hari sebanyak 37 orang (47,4\%). Sedangkan dari 14 ibu hamil yang negatif tidak menderita malaria sebagian besar tidak berada di luar rumah pada malam hari sebanyak 8 orang $(57,1 \%)$ dan selalu berada di luar rumah pada malam hari sebanyak 6 orang (42,9\%). Hasil penelitian ini sejalan dengan peneltian Rahmawati (2014), kebiasaan berada di luar rumah pada malam hari dianggap bermakna secara signifikan terhadap kejadian malaria pada ibu hamil.(17) Tino (2016) juga mengemukakan bahwa kebiasaan berada diluar rumah ada hubungannya dengan kejadian malaria di wilayah kerja puskesmas Ayah Kabupaten Kebumen.(18) Penelitian ini sesuai dengan penelitian Babba (2017) menunjukkan bahwa kebiasaan keluar rumah pada malam hari berpengaru signifikans terhadap kejadian malaria $(\mathrm{p}=0,000)$ dengan nilai OR : 5,54 (95\% CI : 2,37 - 12,98).(19) Hal ini dapat disimpulkan bahwa kebiasaan keluar rumah pada malam hari berpeluang terkena malaria 5,54 kali dibandingkan orang yang tidak keluar rumah pada malam hari. Penelitian ini sesuai dengan penelitian Winardi (2017) yang menyatakan bahwa kebiasaan keluar rumah pada malam hari mempunyai risiko terkena malaria sebesar 6,65 kali dibandingkan dengan yang tidak keluar rumah pada malam hari.(20)

Asumsi peneliti kebiasaan di luar rumah pada malam hari berisiko terjadinya kontak antara orang sehat dengan nyamuk Anopheles spp. yang membutuhkan darah untuk memenuhi siklus gonotropiknya. Jika nyamuk yang menggigit mengandung sporozoid dalam kelenjer ludahnya, maka peluang orang tertular malaria akan semakin besar. Kebiasaan penduduk keluar rumah pada malam hari dilakukan masyarakat Kabupaten Boven Boven Digoel Papua seperti berdagang hinga pukul 22.00 WIT, ngobrol dipinggir pantai, nonton televisi di warung-warung sampai larut malam dengan tubuh yang tidak tertutup secara keseluruhan akan mendukung terjadinya malaria. Upaya yang akan dilakukan sebaiknya memberikan pemahaman akan risiko keluar rumah pada waktu malam hari khususnya kalangan berisiko malaria seperti ibu hamil). 


\section{KESIMPULAN}

Berdasarkan hasil penelitian bahwa dari 78 ibu hamil yang positif menderita malaria sebagian besar menderita anemia sebanyak 51 orang dan tidak menderita anemia sebanyak 27 orang. Kemudian dari 78 ibu hamil yang positif menderita malaria sebagian besar tidak mengalami abortus sebanyak 62 orang dan mengalami abortus sebanyak 16 orang dan dari 78 ibu hamil yang positif menderita malaria sebagian besar selalu berada di luar rumah pada malam hari sebanyak 41 orang dan tidak berada di luar rumah pada malam hari sebanyak 37 orang.

\section{SARAN}

Memaksimalkan informasi kesehatan mengenai pentingnya minum tablet Fe secara teratur sebagai upaya pencegahan anemia. Penyakit malaria pada ibu hamil harus segera diberantas agar Program KIA yang dibuat oleh pemerintah dapat berhasil dan kesehatan pada ibu hamil dapat terjaga, salah satu cara untuk melindungi diri dari gigitan nyamuk yaitu dengan tidak berpergian antara senja dan malam hari karena pada saat itu umumnya nyamuk menggigit serta menggunakan celana panjang dan baju lengan panjang (baju yang menutupi tubuh)

\section{DAFTAR PUSTAKA}

1. Arsin A. Malaria di Indonesia Tinjauan Aspek Epidemiologi. Masagena Press, Makassar; 2012.

2. Rusjdi SR. Malaria Pada Masa Kehamilan. Maj Kedokt Andalas. 2012;36(2):173.

3. Lestari AS, Salamah M. aktor-Faktor yang Mempengaruhi Penyakit Malaria pada Ibu Hamil di Provinsi Nusa Tenggara Barat, Nusa Tenggara Timur, Maluku, Maluku Utara, Papua, dan Papua Barat. Sains Seni ITS. 2014;3(2).

4. (WHO) WHO. World Malaria Report. Geneva: WHO; 2014.

5. Kemenkes RI. Profil Kesehatan Indonesia. Kementrian Kesehatan Indonesia. Pusdatin.Kemenkes.Go.Id. 2014. 182 p.

6. Kesehatan K, Indonesia R. PROFIL KESEHATAN INDONESIA.

7. Masyarakat P, Malaria T, Kota DI. Pengetahuan, Sikap Dan Perilaku Masyarakat Terhadap Malaria Di Kota Batam. Media Penelit dan Pengemb Kesehat. 2012;21(2):47-54.

8. Agoes R dan DN. Parasitolgi Kedokteran ditinjau dari Organ Tubuh yang diserang. Jakarta: EGC; 2009.

9. Gies S, Roberts SA, Brabin BJ, Lompo OM. Risk of malaria in young children after periconceptional iron supplementation. 2021;(June 2020):1-13.

10. Heidkamp RA, Ayoya MA, Teta IN, Stoltzfus RJ, Marhone JP. Complementary feeding practices and child growth outcomes in Haiti: An analysis of data from Demographic and Health Surveys. Matern Child Nutr. 2015;11(4):815-28.

11. Cui L, Mharakurwa S, Ndiaye D, Rathod PK, Rosenthal PJ. Antimalarial drug resistance: Literature review and activities and findings of the ICEMR network. Am J Trop Med Hyg. 2015;93(Suppl 3):57-68.

12. Schellenberg D, Menendez C, Kahigwa E, Aponte J, Vidal J, Tanner M, et al. Intermittent treatment for malaria and anaemia control at time of routine vaccinations in Tanzanian infants: A randomised, placebocontrolled trial. Lancet. 2001;357(9267):1471-7.

13. Dayanand KK, Punnath K, Chandrashekar V, Achur RN, Kakkilaya SB, Ghosh SK, et al. Malaria prevalence in Mangaluru city area in the southwestern coastal region of India. Malar J [Internet]. 2017;16(1):1-10. Available from: https://doi.org/10.1186/s12936-017-2141-0

14. Dwiprahasto I. MALARIA DAN KEHAMILAN: Dampak Terhadap Ibu, Janin dan Bayi serta Potensi Intervensi Kemoprofilaksi. Yogyakarta: Lembaga Penelitian UGM; 2000.

15. Wiguna PA, Yuliani EA, Affarah WS, Reditya NM. Faktor yang Berhubungan dengan Pemberian ASI Eksklusif pada Ibu Bekerja di Kota Mataram. J Kedokt. 2017;5(4).

16. Parker DM, Carrara VI, Pukrittayakamee S, McGready R, Nosten FH. Malaria ecology along the Thailand-Myanmar border. Malar J. 2015;14(1):1-12.

17. Village L, District WK, Tenggara EN. Keanekaragaman jenis dan perilaku menggigit vektor malaria ( Anopheles spp .) di Desa Lifuleo , Kecamatan Kupang Barat, Kabupaten Kupang, Nusa Tenggara Timur Species diversity and biting activity of malaria vectors ( Anopheles spp .). 2014;11(2):53-64.

18. Tino RB, Martini S, W CU, Hidajah AC. Hubungan Faktor Perilaku Pencegahan Terhadap Kejadian Malaria Pada Ibu Hamil. J Penelit Kesehat “SUARA FORIKES” (Journal Heal Res "Forikes Voice") [Internet]. 2016;7(4):217-23. Available from: http://forikes-ejournal.com/index.php/SF/article/view/67

19. Babba I. Faktor - Faktor Risiko Yang Mempengaruhi Kejadian Malaria (Studi Kasus Di Wilayah Kerja Puskesmas This is an open-access article under the CC BY 4.0 International License

(C) An Idea Health Journal (2021) 
Hamadi Kota Jayapura). J Epidemiol. 2007;94-153.

20. Winardi E. Faktor-Faktor Yang Berhubungan Dengan Kejadian Malaria di Kecamatan Selebar kota Bengkulu, Tesis
Universitas
Indonesia.
Ilmu
Kesehat
Masyarakat,
Univ
Indones.
2004; 